\title{
A Novel Work on Performance Appraisal
}

\author{
J. Pavithra, S. Mugundan, V. Nivedha
}

\begin{abstract}
Execution examination is an orderly assessment of present potential abilities of staff and workers by their bosses, unrivaled's prevalent or an expert from outside. It is a procedure of assessing or passing judgment on the worth, fantastic characteristics or status of someone or something. A few associations utilize more than one examination framework for various kinds of workers or for various evaluation purposes. Associations need to gauge representative execution to decide if adequate measures of execution are being kept up.
\end{abstract}

Keywords: Performance appraisal, job evaluation, performance evaluation

\section{INTRODUCTION}

Execution examination is a precise assessment of present potential capacities of staff and representatives by their bosses, unrivaled prevalent or an expert from outside. It is a procedure of assessing or making a decision about the worth, phenomenal characteristics or status of someone or something[1],[3],[5]. It is a procedure of gathering, dissecting and assessing information with respect to work conduct and consequences of people[2],[4],[6]. The examination framework is composed on the guideline of objectives and the executives by targets. The board choices on execution use a few incorporated sources of info: objectives and plans, work assessment, execution assessment, and individual history. It suggests a two-dimensional idea toward one side of the continuum lies the objectives set by the specialist, and at the opposite end, the presentation accomplished by the individual or any given gathering[7],[ 9],[11].

Revised Manuscript Received on July 22, 2019.

J. Pavithra, Department of MBA, Bharath Institute of Higher Education and Research, Chennai, India. Email: pavithralect@yahoo.com

S. Mugundan, Department of MBA, Bharath Institute of Higher Education and Research, Chennai, India.

Email: mugundan784@gmail.com

V. Nivedha, Department of MBA, Bharath Institute of Higher Education and Research, Chennai, India.

Email: nivedhav234@gmail.com

\section{OBJECTIVES OF THE STUDY}

- To distinguish the workers fulfillment towards Performance Appraisal framework[8],[10],[12].

- To comprehend the mindfulness level of representatives about Performance Appraisal framework.

- To break down the representatives desire towards execution evaluation framework

\section{DATA ANALYSIS AND INTERPRETATION}

Table - 1 Performance appraisal successful in giving a clear understanding of the appraisee's job to both

\begin{tabular}{|c|c|c|c|}
\hline S. No & PARTICULARS & $\begin{array}{c}\text { No. OF } \\
\text { RESPONDENTT }\end{array}$ & PERCENTAGE \% \\
\hline 1 & $\begin{array}{c}\text { STRONGLY } \\
\text { AGREE }\end{array}$ & 16 & 14 \\
\hline 2 & AGREE & 46 & 42 \\
\hline 3 & NEUTRAL & 21 & 20 \\
\hline 4 & DIS AGREE & 27 & 24 \\
\hline 5 & STRONGLY & 0 & 0 \\
TIS AGRREE & & 110 & 100 \\
\hline
\end{tabular}

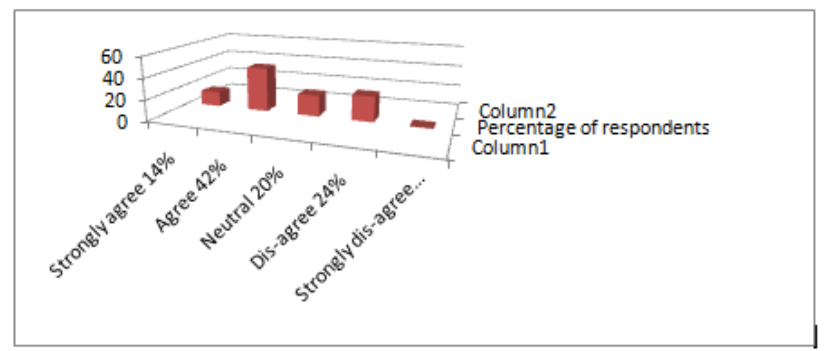

Figure - 1 Performance appraisal successful in giving a clear understanding of the appraisee's job to both

Table - 2 Appraisal system provide good relationship between management and their staff

\begin{tabular}{|c|c|c|c|}
\hline S. No & PARTICULARS & $\begin{array}{c}\text { No. OF } \\
\text { RESPONDENTT }\end{array}$ & PERCENTAGE \% \\
\hline 1 & $\begin{array}{c}\text { STRONGLY } \\
\text { AGREE }\end{array}$ & 32 & 29 \\
\hline 2 & AGREE & 49 & 44 \\
\hline 3 & NEUTRAL & 16 & 15 \\
\hline 4 & DIS AGREE & 13 & 12 \\
\hline
\end{tabular}




\begin{tabular}{|c|c|c|c|}
\hline 5 & $\begin{array}{c}\text { STRONGLY } \\
\text { DIS AGRREE }\end{array}$ & $\mathbf{0}$ & $\mathbf{0}$ \\
\hline TOTAL & & 110 & 100 \\
\hline
\end{tabular}

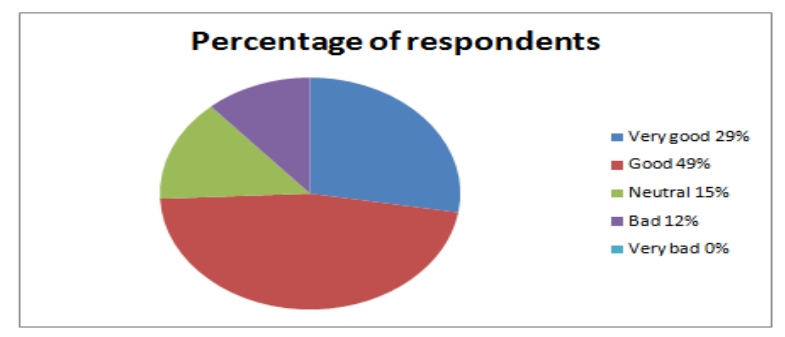

Figure - 2 Appraisal system provide good relationship between management and their staff

Table - 3 Employees Opinion About Performance Appraisal In Rank

\begin{tabular}{|c|c|c|c|}
\hline S. No & PARTICULARS & $\begin{array}{c}\text { No. OF } \\
\text { RESPONDENTT }\end{array}$ & PERCENTAGE\% \\
\hline 1 & $\begin{array}{c}\text { STRONGLY } \\
\text { AGREE }\end{array}$ & 12 & 11 \\
\hline 2 & AGREE & 52 & 47 \\
\hline 3 & NEUTRAL & 26 & 24 \\
\hline 4 & DIS AGREE & 11 & 10 \\
\hline 5 & $\begin{array}{c}\text { STRONGLY } \\
\text { DIS AGRREE }\end{array}$ & 9 & 8 \\
\hline TOTAL & & 110 & 100 \\
\hline
\end{tabular}

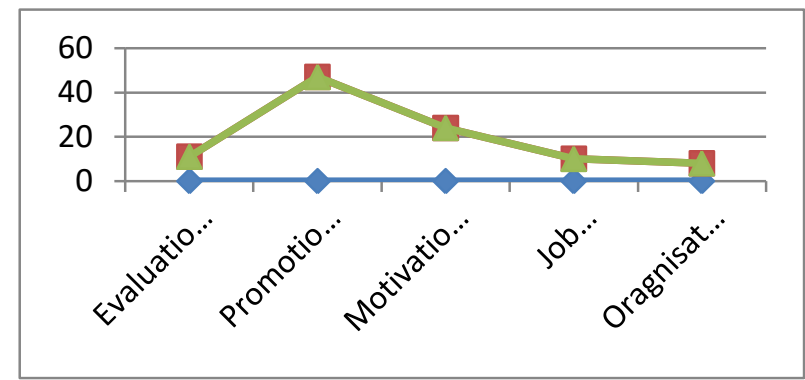

Figure - 3 Employees Opinion About Performance Appraisal In Rank

\section{RESULTS}

1. Major of the respondents (56\%) comprehend about Appraisal's activity, $44 \%$ of respondents didn't comprehend the examinations work[13], [15],[17]

2. Major of respondents $(74 \%)$ in common connection between the board, rest of $26 \%$ of respondents are nonpartisan and awful.

3. $63 \%$ of respondents are in Strongly-concur and concur classification so execution evaluation framework rouse the worker[20],[22], [24].

\section{V.DISCUSSIONS}

1. Performance evaluation framework didn't spur the some classification of representatives so the executives make reach to workers principle content about the Performance examination[25],[27],[29].

2. After execution examination the board need to give quick criticism to workers.

3. The examination credits are not match to some of representatives.

4. Appraisal must be happen genuinely.

\section{CONCLUSION}

Execution Appraisal is a significant apparatus used to impact representatives. Individuals contrast in their capacities and their frames of mind[26],[28],[30]. There is in every case some distinction between the quality and amount of a similar work on a similar activity being finished by two unique individuals. In this way, execution the board and execution examination is important to see every representative's capacities, skills and relative legitimacy and worth for the association. Execution evaluation rates the workers regarding their exhibition[31],[33].

Execution evaluation considers the past exhibition of the representatives and spotlights on the improvement of things to come execution of the workers.

\section{REFERENCES}

1) BharthVajan R., Ramachandran S.,Psychographic dimensions of training,2016,International Journal of Pharmacy and Technology,V-8,I-4,P-23727-23729

2) Balakrishnan P., Bharthvajan R.,A study on human resource planning in hospitals in Chennai City,2014,International Journal of Applied Engineering Research,V-9,I-22,P-7503-7507

3) Priyadarsini P., Bharthvajan R.,Role of emotional intelligence training programme in reducing the stress of the nurses,2014,International Journal of Applied Engineering Research,V-9,I-22,P-7411-7421

4) Kerinab Beenu G., Bharthvajan R.,Empirical analysis on the cosmetic buying behavior of young women in South India,2014,International Journal of Applied Engineering Research,V-9,I-22,P-7361-7366

5) Balakrishnan P., Bharthvajan R.,Whistling in the wind,2014,International Journal of Applied Engineering Research,V-9,I-22,P-7586-7593

6) Krishnan B., Peter M.,Health hazards of Indian Bpo employee-an alarming issue,2014,International Journal of Applied Engineering Research,V-9,I-22,P-7336-7341

7) Kerinab Beenu G.H., Peter M.,Role of insurance in economic development,2014,International Journal of Applied Engineering Research,V-9,I-22,P-7532-7539

8) Balakrishnan P., Peter M., Priyadarsini P.,Efficiency of safety measures for wellbeing of employees in manufacturing industry,2014,International Journal of Applied Engineering Research,V-9,I-22,P-7376-7382

9) Anbarasi M., Praveen Kumar S.,Online sales promotions of herbal products and its effectiveness towards tanisha.com,2019,Indian Journal of Public Health Research and Development,V-10,I-1,P-195-200

10) Anbarasi M., Praveen Kumar S.,Various online marketing and promotions strategies to improve the validation towards the organic products in the pharmaceutical sectors,2019,Indian Journal of Public Health Research and Development,V-10,I-1,P-263-269

11) Loganathan R., Praveen Kumar S.,Grievance handling a key factor for solving issues of employees in an organization,2014,International Journal of Applied Engineering Research,V-9,I-22,P-7483-7491

12) Loganathan R., Praveen Kumar S.,Study on preference of private label brands in super and Hypermarkets,2014,International Journal of Applied Engineering Research,V-9,I-22,P-7327-7335

13) Smitha M., Praveen Kumar S.,Understanding stress and its managementamong the nurses in Chennai city,2014,International Journal 
of Applied Engineering Research,V-9,I-22,P-7560-7565

14) Kerinab Beenu G.H., Praveen Kumar S.,A study on the investment behavior of Chennai investors in mutual fund schemes,2014,International Journal of Applied Engineering Research,V-9,I-22,P-7520-7525

15) Loganathan R., Praveen Kumar S.,Retention strategies key for organizational productivity,2014,International Journal of Applied Engineering Research,V-9,I-22,P-7443-7447

16) Pavithra J., Ganesan M., Brindha G.,State wise analysis of microfinance sector in India,2016,International Journal of Pharmacy and Technology,V-8,I-4,P-23417-23432

17) Pavithra J., Ganesan M.,A comparative study on microfinance in India and abroad,2016,International Journal of Applied Business and Economic Research,V-14,I-8,P-5471-5476

18) Pavithra J., Ganesan M.,A study on awareness and impact of micro-financial schemes,2016,International Journal of Applied Business and Economic Research,V-14,I-8,P-5449-5460

19) Senthilmurugan P., Pavithra J.,Consumer preference towards organised retailing with reference to Big Bazaar,2014,International Journal of Applied Engineering Research,V-9,I-22,P-7469-7475

20) Senthilmurugan P., Pavithra J.,Implication of social media marketing in growing healthcare industry,2014,International Journal of Applied Engineering Research,V-9,I-22,P-7448-7456

21) Loganathan R., Pavithra J.,Consumer perception towards private label brand over other brands in super markets and hypermarkets,2014,International Journal of Applied Engineering Research,V-9,I-22,P-7355-7360

22) Kerinab Beenu G., Pavithra J.,Tradeâe“off between liquidity and profitability in logistics industry,2014,International Journal of Applied Engineering Research,V-9,I-22,P-7398-7401

23) Kerinab Beenu G., Pavithra J.,A study on the prospective consumerâ $€^{\mathrm{TM}_{\mathrm{S}}}$ perception towards utility cars in Chennai city,2014,International Journal of Applied Engineering Research,V-9,I-22,P-7526-7531

24) Pavithra J., Dilli Babu P., Ambuli T.V.,A study on budgetary control at Maruti Service Masters, Chennai,2014,International Journal of Applied Business and Economic Research,V-12,I-2,P-151-161

25) Pavithra J., Dilli Babu P., Ambuli T.V.,A study on customer satisfaction of retro Garments Pvt Ltd, Chennai,2014,International Journal of Applied Business and Economic Research,V-12,I-2,P-381-391

26) Kerinab Beenu G.H., Pavithra J., Senthilmurugan P.,A study on the influence of promotional activities for TATA ARIA among consumers in Chennai,2014,International Journal of Applied Engineering Research,V-9,I-22,P-7572-7578

27) Vijayaragavan S.P.,An investigative expert that's general FBG sensors,International Journal of Mechanical Engineering and Technology,V-8,I-8,PP-1500-1505,Y-2017

28) Vijayaragavan S.P.,Equalization routing protocol for Wi-Fi sensor strategy,International Journal of Mechanical Engineering and Technology,V-8,I-8,PP-1662-1666,Y-2017

29) Karthik B., Kiran Kumar T.V.U., Vijayaragavan P., Bharath Kumaran E.,Design of a digital PLL using $0.35 \mathrm{1}^{1} / 4 \mathrm{~m}$ CMOS technology,Middle East Journal of Scientific Research,V-18,I-12,PP-1803-1806,Y-2013

30) Kanniga E., Selvaramarathnam K., Sundararajan M.,Kandigital bike operating system,Middle - East Journal of Scientific Research,V

31) Jasmin M., Vigneshwaran T., Beulah Hemalatha S.,Design of power aware on chip embedded memory based FSM encoding in FPGA,International Journal of Applied Engineering Research,V-10,I-2,PP-4487-4496,Y-2015

32) Jasmin M.,Optimization techniques for low power VLSI circuits,Middle East Journal of Scientific Research,V-20,I-9,PP-1082-1087,Y-2014

33) Jasmin M., Vigneswaran T.,Fuzzy controller for error control of on - Chip communication,2017 International Conference on Algorithms, Methodology, Models and Applications in Emerging Technologies, ICAMMAET 2017,V-2017-January,I-,PP-1-5,Y-2017

\section{AUTHORS PROFILE}

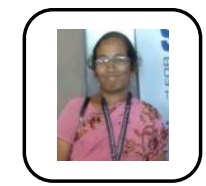

J. Pavithra Assistant Professor, Department of MBA, Bharath Institute of Higher Education and Research, Chennai, India.

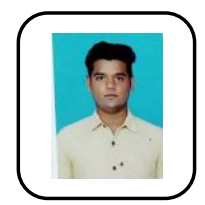

S. Mugundan Student, Department of MBA, Bharath Institute of Higher Education and Research, Chennai, India.

V. Nivedha Student, Department of MBA, Bharath Institute of Higher Education and Research, Chennai, India. 